\title{
Högbomite Associated with Vanadium bearing Titaniferous Magnetite of Mafic-Ultramafic Suite of Moulabhanj Igneous Complex, Orissa, India
}

\author{
D. Beura ${ }^{1 *}$, D. Acharya ${ }^{2}$, P. Singh ${ }^{1}$ and S. Acharya ${ }^{3}$ \\ ${ }^{1}$ Department of Geology, Utkal University, Bhubaneswar \\ ${ }^{2}$ Stewart Science College, Cuttack \\ 3 155, V.I.P. Colony, Nayapalli, Bhubaneswar \\ *Corresponding Author: debanandabeura@rediffmail.com
}

\begin{abstract}
Högbomite associated with vanadium bearing titaniferous magnetite has been identified in mafic-ultramafic suite of rocks of Moulabhanj, Orissa, India. The igneous complex intruded into granulite terrain of Eastern Ghat Super Group. The iron mineral assemblages are Ti-V magnetite, martite and ilmenite. Högbomite occurs in association with Ti-V magnetite and exhibits both primary and secondary micro-textures. EPMA study confirms the presence of högbomite.
\end{abstract}

Key Words: Högbomite, Ti-V Magnetite, EPMA, Moulabhanj

\section{INTRODUCTION}

Högbomite a complex oxide of $\mathrm{Fe}, \mathrm{Mg}, \mathrm{Al}$ and $\mathrm{Ti}$ is an important constituent of Fe-Ti-oxide of igneous (basic-ultrabasic) complex of Moulabhanj area $\left(20^{0} 56^{\prime} \mathrm{N}\right.$ : $\left.85^{\circ} 43^{\prime} \mathrm{E}\right)$ of Orissa, India. The mineral was first reported by Gavelin [1] from Swedish Lapland and later in various places in the world. In India, Devaraju et al., [2] reported högbomite in Fe-Ti oxide from Madangere of Karnataka and Mohanty et al., [3-4] described from Boula-Nausahi igneous complex of Orissa. Reports on this new locality suggests that högbomite may be more wide spread than in general perceived.

Presently studied Ti-V magnetite ore bodies hosted in mafic-ultramafic suites have been invaded into the granite gneisses and granulites near the border zone between Iron Ore Supergroup 
(IOSG) and Eastern Ghat Supergroup (EGSG) at Moulabhanj ( $20^{\circ} 56^{\prime} \mathrm{N}$ : $\left.85^{\circ} 43^{\prime} \mathrm{E}\right)$, Dhenkanal district, Orissa, India [5]. The two Supergroups exhibiting contrasting characters in terms of lithology, structure and grade of metamorphism are separated by migmatite and mafic granulites and are separated by Sukinda thrust zone (STZ) running east west. Moulabhanj igneous complex crop out within EGSG in the south of STZ and the well-known Sukinda valley chromite field is lying in the north. The complex hosted chromite, magnetite and högbomite. The ore microscopic study was carried out at Department of Geology, Utkal University whereas EPMA studies were done at IIT- Roorkee, Roorkee.

\section{GEOLOGICAL SET UP}

The present study area around Moulabhanj $\left(20^{\circ} 56^{\prime} \mathrm{N}: 85^{\circ} 43^{\prime} \mathrm{E}\right)$ is lying within Easternghats constituting southern part of the contact zone (STZ) between IOSG and EGSG. Ore bearing mafic and ultramafic complexes have intruded into metamorphites of Easternghats belongs to Proterozoic. The litho-types of the area comprises of charnockite, khondalite, migmatitic gneiss, quartzo-feldspathic gneiss and pyroxene granulite, which are invaded by pegmatite and dolerite dyke (Fig. 1).

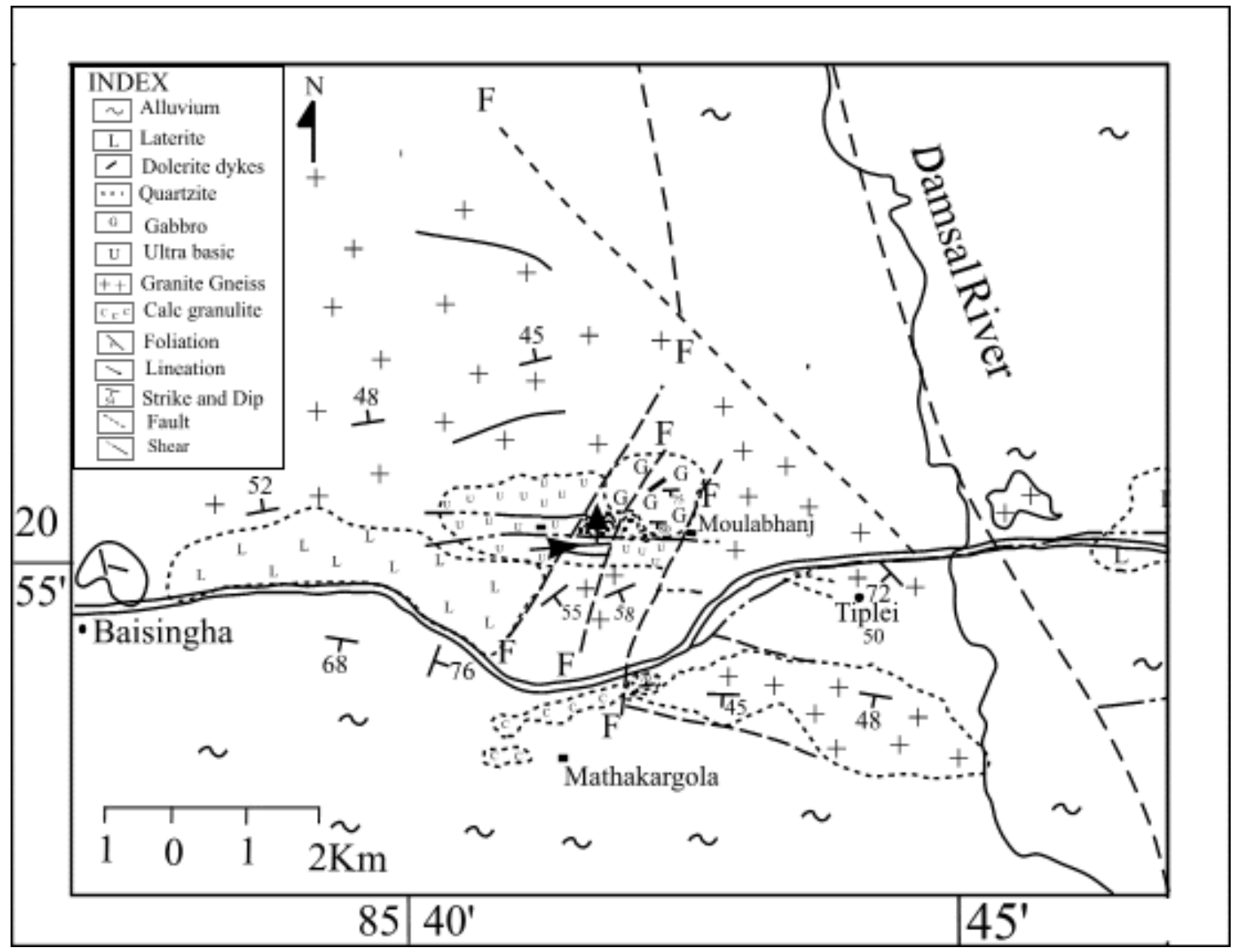

Fig. 1. Geological map of Moulabhanj, Orissa. 
The mafic-ultramafic complexes of the study area are represented by peridotite, pyroxenite, gabbro and their alteration products. It hosts chromite and V-Ti- magnetite. The other minerals present are ilmenite, martite, spinel, hematite, goethite and chlorite. The lithosomes reveal greenschist facies assemblages in contrast to the high-grade metamorphism of the rocks of EGSG into which they have intruded. Magnetite is intimate in association with gabbro suite of rocks, which is exposed as discordant bodies in the region.

In fact, the chromite and Ti-V-magnetite bearing ultramafic -mafic suites emplaced across the contact zone are less deformed and metamorphosed. Thus, they are assumed to be invaded into the zone under rifting only after granitic activity, metamorphism and fold movements.

\section{PETROGRAPHY}

Petrographic study of titaniferous magnetite was carried out by ore microscopic analysis (Leica labour lux 12 pol. and Leica DM 2500 P). Various minerals identified are magnetite, martite, ilmenite, spinel, högbomite and chlorite. (Fig.2 and Fig.3). Högbomite occurs as fine- to medium-grained euhedral to subhedral crystals enclosed within or along grain boundaries of magnetite and ilmenite and associated with spinel and chlorite. It is commonly granular in habit with tabular, prismatic and slender shape. It is also found intergrown and included with other minerals and often shows twinning may be repeated type.

Högbomite is opaque mineral but transparent in thin fragments. It is dark in colour and brown in transmitted light. It exhibits pinkish grey colour, feeble pleochroism, lower reflectivity $(<10 \%)$, anisotropism and reddish brown internal reflection under reflected light (Fig. 2 and Fig. 3).

Studies indicate wide spectrum of crystal habits of högbomite. Idiomorphic grains exhibit rhombohedral, bipyramidal and hexagonal habit (Fig. 2. A, B, C and D). Subhedral grains of prismatic and platy högbomite are present within magnetite (Fig.3.A) and interfaces of magnetite and ilmenite (Fig. 2.D).

Small blebs and drops of högbomite within magnetite and ilmenite demonstrate the exsolution phase/texture (Fig. 3.C). Exsolved ilmenite in magnetite and exsolved hematite in ilmenite is the common textural pattern also traced in slides (Fig. 2.C and Fig. 3.B \& C). Unmixing of solid solutions of these minerals occurred during the post magmatic stage.

Högbomite in forms of small grains that occur along the margins of magnetite appears either to replace magnetite or to overgrow on it. In cases, larger grains of högbomite replace magnetite and overgrown on it to emerge magnetite as inclusion that may be considered as part of replacement process (Fig. 2.A). Two generations of högbomite exist having been separated by magnetite. The earlier phase of subhedral högbomite in magnetite has been replaced by 
subsequent phase of anhedral högbomite leaving vestige magnetite as a ring (Fig. 3.D). Incipient growth of högbomite along the boarder of magnetite grain on the backdrop of martitised magnetite indicates gradual replacement of magnetite (Fig. 3.F).

Most of the högbomite grains are rimmed by dark coloured chlorite of varying thickness. Presence of chlorite along the grain boundaries of högbomite indicates the alteration of the later from the earlier (Fig. 2.A, B and Fig. 3.A, F). Often högbomite shows replacement texture in which overgrowth spinel and magnetite are replaced by it (Fig. 3.F). Twining habit of hexagonal högbomite exist may be due to growth phenomena rather than pressure (Fig. 2.D).
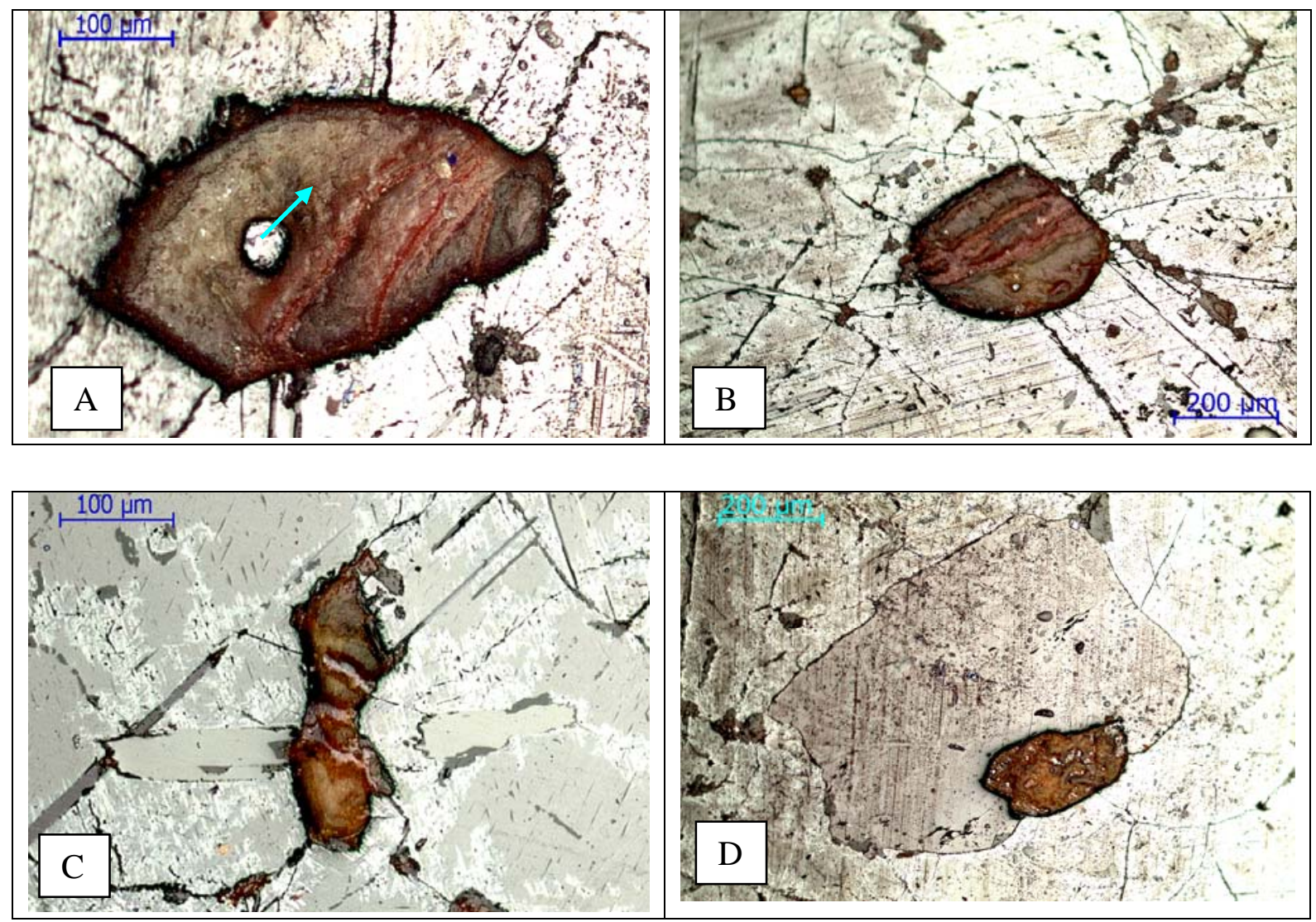

Fig. 2. Photomicrograph of (A) Well-developed hexagonal högbomite (Hg) crystal with magnetite (Mg) inclusion rimmed by dark coloured chlorite (Cl). (B) Bipyramidal crystal of högbomite (Hg) in magnetite. Magnetite is partly altered to martite (Mt). (C) Rhombohedral grains of högbomite $(\mathrm{Hg})$ enclosed in martitised magnetite. The exsolved ilmenite is cut by ilmenite plate, which in turn replaced by högbomite. (D) Hexagonal twin-crystals of högbomite (Hg) exist in the interface of ilmenite (IL) and magnetite.

The Ti-V-magnetite exhibits polycrystalline granular texture the grain boundaries show triple point junction (Fig. 3.D). It consistently demonstrates ex-solution lamellae/stringers of ilmenite and partial martitisation along grain boundaries and cleavage planes. Hematite containing 
ilmenite exsolution lamellae is more abundant than independent (primary) ilmenite. Minor secondary chlorite is ubiquitous.
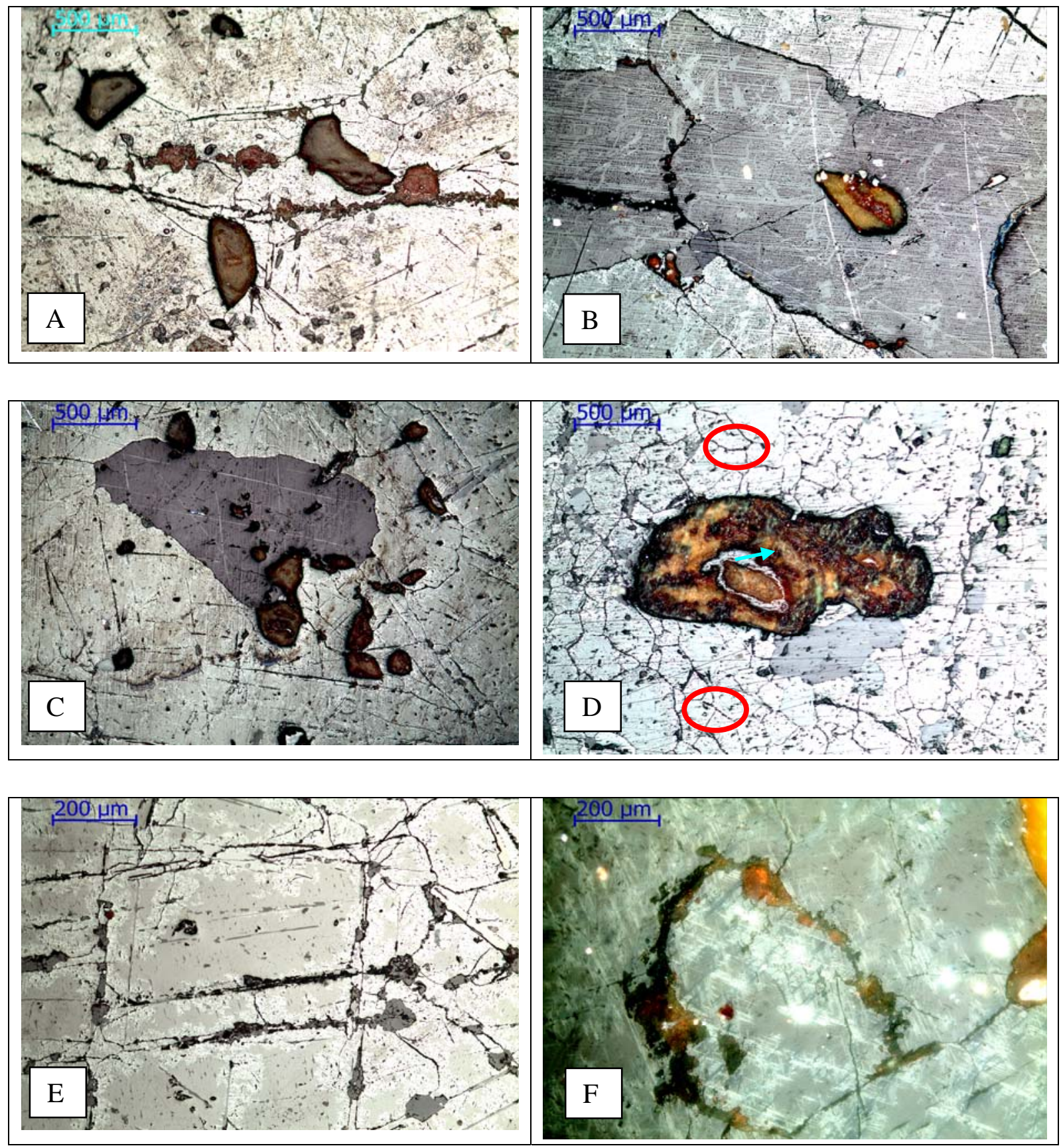

Fig.3. Photomicrograph of (A) Subhedral platy and prismatic crystals högbomite (Hg) within magnetite. (B) Högbomite (Hg) of subhedral habit occurs within ilmenite. Note that ilmenite shows exsolution lamellae of hematite. (C) Belbs and drops of högbomite grains lying within and along the boundary of ilmenite shows exsolution texture. Exsolution lamellae of hematite are seen in ilmenite (D) Earlier subhedral grain of högbomite (Hg) in magnetite is replaced by later anhedral högbomite (Hg) leaving vestige magnetite as a ring. Note that magnetite grains shows 
triple point junction $(\mathrm{O})$ with interfacial angle of $120^{\circ}$ (E) Högbomite grains are oriented parallel to the exsolved ilmenite lamellae/lath by replacing it. It indicates högbomite (Hg) is formed latter to the ilmenite. (F) Högbomite grains along with dark coloured chlorite grains replace martitised magnetite forming ring around Magnetite showing widmansttaten texture.

\section{MINERAL CHEMISTRY}

Mineralogical identification of Ti-V magnetite was carried out by ore microscopic analysis that indicates presence of magnetite, martite, ilmenite and högbomite in them. The presence of högbomite is confirmed by EPMA (JEOL JXA-8600 M, SPI standards with an accelerating voltage of $15 \mathrm{KV})$.

Högbomite is a rare mineral whose chemical formula is $\mathrm{R}^{\mathrm{II}}{ }_{1.0-1.6} \mathrm{Ti}_{0 \cdot 2-0.4} \mathrm{R}^{\mathrm{III}}{ }_{3.7-4.3} \mathrm{O}_{8}$ (where $\mathrm{R}^{\mathrm{II}}=$ Fe, $\mathrm{Zn}, \mathrm{Mg} ; \mathrm{R}^{\mathrm{III}}=\mathrm{Fe}, \mathrm{Al}$ ) [6]. The results of selected four spots examined by Electron Probe Microanalysis (EPMA) are tabulated. The element compositions obtained are given in Table 1. The Ti-V magnetite exhibits granular texture. Magnetite contains $\mathrm{TiO}_{2}, \mathrm{Al}_{2} \mathrm{O}_{3}, \mathrm{MnO}, \mathrm{MgO}$, $\mathrm{V}_{2} \mathrm{O}_{3}$ and $\mathrm{ZnO}$ (Table 2). Ilmenite contains $\mathrm{TiO}_{2}, \mathrm{Al}_{2} \mathrm{O}_{3}, \mathrm{Cr}_{2} \mathrm{O}_{3}, \mathrm{MnO}, \mathrm{MgO}$ and $\mathrm{V}_{2} \mathrm{O}_{3}$ (Table 3).

Table 1. Chemical analysis of Moulabhanj högbomite.

\begin{tabular}{|l|l|l|l|l|}
\hline $\begin{array}{l}\text { Sample No } \\
\cdot\end{array}$ & $56 / 10$ & $56 / 14$ & $58 / 3$ & $58 / 9$ \\
\hline $\mathrm{FeO}^{\mathrm{t}}$ & 26.86 & 27.91 & 25.9 & 28.49 \\
\hline $\mathrm{TiO}_{2}$ & 4.36 & 4.34 & 4.38 & 4.26 \\
\hline $\mathrm{MgO}$ & 9.31 & 8.42 & 9.62 & 8.23 \\
\hline $\mathrm{Al}_{2} \mathrm{O}_{3}$ & 56.28 & 56.22 & 57.73 & 56.19 \\
\hline $\mathrm{MnO}^{\mathrm{Cr}_{2} \mathrm{O}_{3}}$ & 0.15 & 0.15 & 0.13 & 0.06 \\
\hline $\mathrm{ZnO}^{\mathrm{SiO}} \mathrm{F}_{2}$ & 0.05 & 0.04 & 00 & 0.05 \\
\hline $\mathrm{V}_{2} \mathrm{O}_{3}$ & 1.61 & 1.51 & 1.99 & 1.48 \\
\hline $\mathrm{Total}$ & 0.00 & 0.32 & 00 & 0.01 \\
\hline & 0.03 & 0.02 & 0.02 & 0.01 \\
\hline & 98.65 & 98.92 & 99.77 & 98.78 \\
\hline
\end{tabular}


Table 2. EPMA of Magnetite grains.

\begin{tabular}{|l|l|l|l|l|l|l|}
\hline $\begin{array}{l}\text { Sample No } \\
.\end{array}$ & $56 / 1$ & $56 / 6$ & $56 / 9$ & $58 / 1$ & $58 / 4$ & $58 / 10$ \\
\hline $\mathrm{FeO}^{\mathrm{t}}$ & 87.100 & 85.577 & 86.176 & 90.047 & 89.649 & 90.685 \\
\hline $\mathrm{TiO}_{2}$ & 2.775 & 2.330 & 1.838 & 2.287 & 1.162 & 1.1712 \\
\hline $\mathrm{MgO}$ & 0.271 & 0.913 & 0.330 & 0.0542 & 0.170 & 0.138 \\
\hline $\mathrm{Al}_{2} \mathrm{O}_{3}$ & 0.949 & 5.424 & 1.880 & 1.377 & 1.043 & 1.371 \\
\hline $\mathrm{MnO}$ & 0.113 & 0.061 & 0.030 & 0.048 & 0.165 & 0.022 \\
\hline $\mathrm{Cr}_{2} \mathrm{O}_{3}$ & 0.079 & 0.027 & 0.048 & 0.122 & 0.000 & 0.000 \\
\hline $\mathrm{ZnO}^{\mathrm{SiO}}{ }_{2}$ & 0.104 & 0.000 & 0.000 & 0.000 & 0.051 & 0.000 \\
\hline $\mathrm{V}_{2} \mathrm{O}_{3}$ & 0.000 & 0.000 & 0.000 & 0.000 & 0.000 & 0.000 \\
\hline $\mathrm{Total}$ & 0.015 & 0.012 & 0.013 & 0.011 & 0.011 & 0.011 \\
\hline & 91.407 & 94.344 & 90.314 & 94.436 & 92.701 & 93.939 \\
\hline
\end{tabular}

Table 3. EPMA of ilmenite grains.

\begin{tabular}{|l|l|l|l|l|l|l|}
\hline $\begin{array}{l}\text { Sample No } \\
.\end{array}$ & $56 / 2$ & $56 / 4$ & $56 / 11$ & $58 / 2$ & $58 / 8$ & $58 / 10$ \\
\hline $\mathrm{FeO}^{\mathrm{t}}$ & 45.87 & 46.27 & 45.14 & 45.66 & 47.48 & 44.11 \\
\hline $\mathrm{TiO}_{2}$ & 51.73 & 52.06 & 52.20 & 52.79 & 51.54 & 53.31 \\
\hline $\mathrm{MgO}$ & 1.30 & 1.112 & 1.13 & 1.29 & 1.42 & 1.27 \\
\hline $\mathrm{Al}_{2} \mathrm{O}_{3}$ & 0.00 & 0.00 & 0.03 & 0.05 & 0.10 & 0.09 \\
\hline $\mathrm{MnO}^{\mathrm{Cr}} \mathrm{O}_{3}$ & 0.57 & 0.84 & 0.70 & 0.65 & 0.60 & 0.80 \\
\hline $\mathrm{ZnO}^{\mathrm{SiO}}{ }_{2}$ & .081 & 0.04 & 0.12 & 0.01 & 0.00 & 0.04 \\
\hline $\mathrm{V}_{2} \mathrm{O}_{3}$ & 0.00 & 0.10 & 0.04 & 0.07 & 0.00 & 0.04 \\
\hline $\mathrm{Total}$ & 0.00 & 0.00 & 0.00 & 0.00 & 0.00 & 0.00 \\
\hline
\end{tabular}

The matrix högbomite is presumed to have formed from magnetite but there is no obvious source of $\mathrm{Al}$, alternatively the present magnetite-högbomite-ilmenite aggregates could have resulted from recrystallization and oxidation of a pre-existing Fe-Mg-Ti-Mn phase (+ilmenite). In the different composition, the matrix högbomite must have formed from a different mix of oxide phases. Thereby implying compositional factors, including oxygen fugacity, rather than pressure and temperature, are main controls of högbomite chemistry.

The average analysis of samples is given in Table 1. It is richer in $\mathrm{Al}$ and impoverished in Ti. Higher $\mathrm{FeO}$ and $\mathrm{ZnO}$, nearly lacks $\mathrm{Cr}_{2} \mathrm{O}_{3}$ and $\mathrm{MnO}$. Compared to the högbomite from Karnataka 
[2] and Baula-Nausahi, Orissa [4], these are richer in MgO, $\mathrm{Zn}$ and poor in Ti, Mn, Cr. Ti-poor högbomites have also been reported [7, 8]. $\mathrm{Zn}$ is commonly present in appreciable amounts (1.48 $-1.99 \mathrm{wt} \% \mathrm{ZnO})$.

There is reciprocal relationship between $\mathrm{Fe}$ and $\mathrm{Mg}, \mathrm{Fe}$ and $\mathrm{Ti}$ and $\mathrm{Fe}$ and $\mathrm{Al}$ indicate that $\mathrm{Ti}$, $\mathrm{Mg}$ and $\mathrm{Al}$ replace $\mathrm{Fe}$ in the högbomite structure. Low concentration of $\mathrm{Mg}$ in the mineral derived from the magma having very-low MgO content [7-9]. Chemically the högbomite is characterized by (i) narrow variation in alumina and titania values, (ii) consistently high $\mathrm{Zn}$ values, (iii) moderate $\mathrm{Mn}, \mathrm{Cr}$ and $\mathrm{V}$ values similar to the co-existing magnetite, (iv) substitution of Mg and Zn by Ti results in the replacement of spinel by högbomite.

\section{DISCUSSION AND CONCLUSION}

Högbomite of Moulabhanj area is traced in Ti-V-magnetite; spinel and chlorite association, which suggests that it is a part of the magmatic phenomenon. The magmatic derivation is evidenced by absence of metamorphism. Morphologically it can be grouped into primary crystallized from the magma as exsolution and secondary- developed after spinel through alteration.

Högbomite exists as coarse grain and its randomly orientation in interstices of the ore minerals suggest an early-crystallized pyrogenic phase. Thin scales/rods and small blebs of högbomite occurring within magnetite represent the exsolved phase; the exsolution of högbomite component may be due to falling temperature of crystallization [2]. Small patches within the magnetite possibly demonstrate exsolution phase of högbomite. The slender scales and shreds of högbomite rimming the spinel grains bear evidence of formation at the expense of spinel [10, 11]. According to Jayaraj et al., [9] the early-formed spinel crystals reacted partially with the magma resulting in högbomite rims.

According to Grew et al., [8] högbomite occurs in association with spinel and chlorite points to the secondary nature of högbomite. The högbomite associated with spinel is formed by the substitution of $\mathrm{Ti}^{2+}$ for $\left(\mathrm{Mg}^{2+}, \mathrm{Fe}^{2+}\right)$ and $\mathrm{Fe}^{2+}$ for $\mathrm{Al}^{3+}$ under silica under-saturation and high oxygen fugacity condition [4].

In a thermodynamic treatment of the stability of högbomite, Petersen et al., [12] proposed a number of högbomite-forming reactions that included the breakdown of magnetite and spinel. Substitution of Mg and $\mathrm{Zn}$ by Ti according to Friedman [10] is the mechanism of högbomite formation. Zakrzewski [11] suggested that the loss of $\mathrm{Al}$ in högbomite is compensated by oxidation of magnetite as usually högbomite is noted along margin of magnetite.Relationships of högbomite with ilmenite, magnetite and chlorite show that its crystallization took place after formation of the ore minerals but before or simultaneously with chlorite. 


\section{REFERENCES}

[1] Gavelin, A., 1916, “Uber högbomite.” Bull.Geol. Inst. Uni, Upsala Vol.15, pp. 289- 316.

[2] Devaraju, T.C., Uttangi, V. H. and Coolen, J.J.M.M.M., 1981, "Högbomite from Fe-Ti deposit of Madangere, Ankola Taluk, Karnataka.” Jour. Geol. Soc. Ind, Vol.22 pp. 439- 443.

[3] Mohanty, J.K., Sahoo, R.K., and Paul, A.K., 1995, "Research note on Högbomite from Fe-Ti oxide deposit, Boula-Nausahi igneous complex.” Ind. Miner. Vol. 49 (4), pp. 293-294

[4] Mohanty, J.K., Khaoash, S. and Paul, A.K., 2000, "Högbomite from Fe-Ti oxide deposit, Boula-Nausahi igneous complex, Keonjhar district, Orissa, India.” Acta Mine-Petr. Szeged, Vol. XLI, pp. 3-8.

[5] Acharya, S., Singh, P., Das, M., Sahoo, N.K. and Acharya, D., 1997, “The Sukinda thrust An enigma.” Vista. Geol. Reas. Spl. Publ, No. 2, pp. 251-258.

[6] Grew, E. S., Drugova, G.M., Leskova N.V., 1989, "Högbomite from the Aldan Shield, eastern Siberia, USSR.” Mineralogical Mag, Vol. 53, pp. 376-379.

[7] Mancktelow, N. S., 1981, “Hogbomite of unusual composition from Reedy Creek, S. Africa.' Min. Mag. Vol. 44, pp. 91-94.

[8] Grew, E. S., Hiroi, Y. and Shiraishi, K., 1990, "Högbomite from the Prince Olav Coast, East Antarctika: An example of oxidation-exsolution of a complex magnetite solid solution?” Am. Mineral, Vol. 75, pp. 589-600.

[9] Jayaraj, K.R., Khanadali, S.D., Devaraju, T.C. and Spiering, B., 1995, “A study of högbomite in the V-Ti-Fe deposits of Karnataka.” J. Geol. Soc. Ind, Vol. 45, pp. 57-64.

[10] Friedman, G.M., 1952, “Study of högbomite.” Am. Minerl, Vol. 37, pp.600-608.

[11] Zakrzewski, M.A., 1977, “Högbomite from the Fe-Ti deposit of Liganga (Tanzania).” N. Jb. Min. Mh. H-8, pp.273 - 280.

[12] Petersen, L.U., Essene, E.J., Peacor, D.R. Marcouy, L.A., 1988, “The occurrence of högbomite in high-grade metamorphic rocks.” Contri. Mineral. Petrol. Vol.101, pp.350360. 